\title{
Relay cross metathesis reactions of vinylphosphonates
}

\author{
Raj K. Malla, Jeremy N. Ridenour and Christopher D. Spilling ${ }^{*}$
}

\author{
Full Research Paper \\ Address: \\ Department of Chemistry and Biochemistry, University of Missouri St. \\ Louis, One University Boulevard, St. Louis, MO 63121, USA \\ Email: \\ Christopher D. Spilling ${ }^{*}$ - cspill@umsl.edu \\ * Corresponding author \\ Keywords: \\ centrolobine; metathesis; organo phosphorus; relay; vinyl \\ phosphonate
}

Open Access

\author{
Beilstein J. Org. Chem. 2014, 10, 1933-1941.
}

doi:10.3762/bjoc. 10.201

Received: 23 January 2014

Accepted: 14 July 2014

Published: 19 August 2014

This article is part of the Thematic Series "Organophosphorus chemistry".

Guest Editor: P. R. Hanson

() 2014 Malla et al; licensee Beilstein-Institut. License and terms: see end of document.

\begin{abstract}
Dimethyl ( $\beta$-substituted) vinylphosphonates do not readily undergo cross metathesis reactions with Grubbs catalyst and terminal alkenes. However, the corresponding mono- or diallyl vinylphosphonate esters undergo facile cross metathesis reactions. The improved reactivity is attributed to a relay step in the cross metathesis reaction mechanism.
\end{abstract}

\section{Introduction}

Over the last two decades, we have developed reactions for the formation of chiral non-racemic $\gamma$-substituted vinylphosphonates [1-9]. In particular, carbonate derivatives 1 (phosphono allylic carbonates) of allylic hydroxy phosphonates undergo palladium-catalyzed addition of nucleophiles to give $\gamma$-substituted vinylphosphonates 2 in high yield (Scheme 1). The nucleophile adds exclusively to the 3-position, with migration of the double bond into "conjugation" with phosphoryl group. As expected, the reactions generally proceed with complete chirality transfer. Various carbon, nitrogen, and oxygen nucleophiles participate in the palladium-catalyzed substitution reactions of phosphono allylic carbonates $\mathbf{1}$. Vinylphosphonates formed in this way, for example 2a-e (Figure 1), have been used in the synthesis of the natural products turmerone [4] and enterolactone [5], the phosphonate derivatives of the natural product cyclophostin [6], the C18-C34 fragment of amphidinolide C [7], and the oxylipids from Australian brown algae [8].

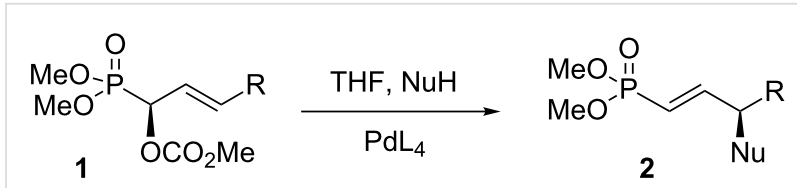

Scheme 1: Palladium catalysed reaction of phosphono allylic carbonates.

The potential of vinylphosphonates as intermediates in organic synthesis is limited by their chemistry. Unlike the parent compound, vinylphosphonates substituted with an aryl or alkyl group on the alkene appear to have somewhat limited reactivity. This lack of reactivity is exemplified by the Grubbs cross metathesis reaction [10]. Grubbs and co-workers classified terminal vinylphosphonates as type III substrates [11]. Type III alkenes do not homodimerize, but will engage in alkene cross metathesis reactions. However, we have observed that $\beta$-substi- 
<smiles>CCCCCC1O[C@@H](/C=C/P(=O)(OC)OC)C[C@H]1O</smiles>

tumerone<smiles>C=C(CCCC)C([OH2+])/C(C)=C/C=C/C(O)[C@H]1CC[C@@H](CCOC(C)(C)C)O1</smiles>

C18-C34 frgament of amphidinolide $\mathrm{C}$<smiles>COCCC1CCC(/C=C/P(=O)(OC)OC)O1</smiles>

2d

Figure 1: Natural products prepared using vinyl phosphonate intermediates.

tuted vinylphosphonates are unreactive towards cross metathesis and are therefore type IV substrates. Since alkene cross metathesis is a powerful method of combing organic fragments in natural product synthesis, the value of vinylphosphonates as synthetic intermediates would increase if their reactivity could be enhanced to a level where they would participate in cross metathesis reactions.
As an example, we recently described a method for the formal synthesis of centrolobine (8) [9], an antileishmananial compound isolated from the heartwood of various Centrolobium species [12-16] (Scheme 2). The cis-THP substituted vinylphosphonate $\mathbf{5}$, formed by a stereospecific palladium-catalyzed cyclization of phosphono allylic carbonate 4 , was cleaved via ozonolysis to the aldehyde $\mathbf{6}$, a known intermediate $[17,18]$ on<smiles>C=CCCCC(O)c1ccc(OC)cc1</smiles>

3<smiles>C=CC(OC(C)=O)P(=O)(OC)OC</smiles>

4

$$
\begin{gathered}
\mathrm{Pd}_{2}(\mathrm{dba})_{3}, \mathrm{dppe} \\
\mathrm{iPr}_{2} \mathrm{NiEt}, \mathrm{THF}, 60^{\circ} \mathrm{C} \\
85 \%
\end{gathered}
$$

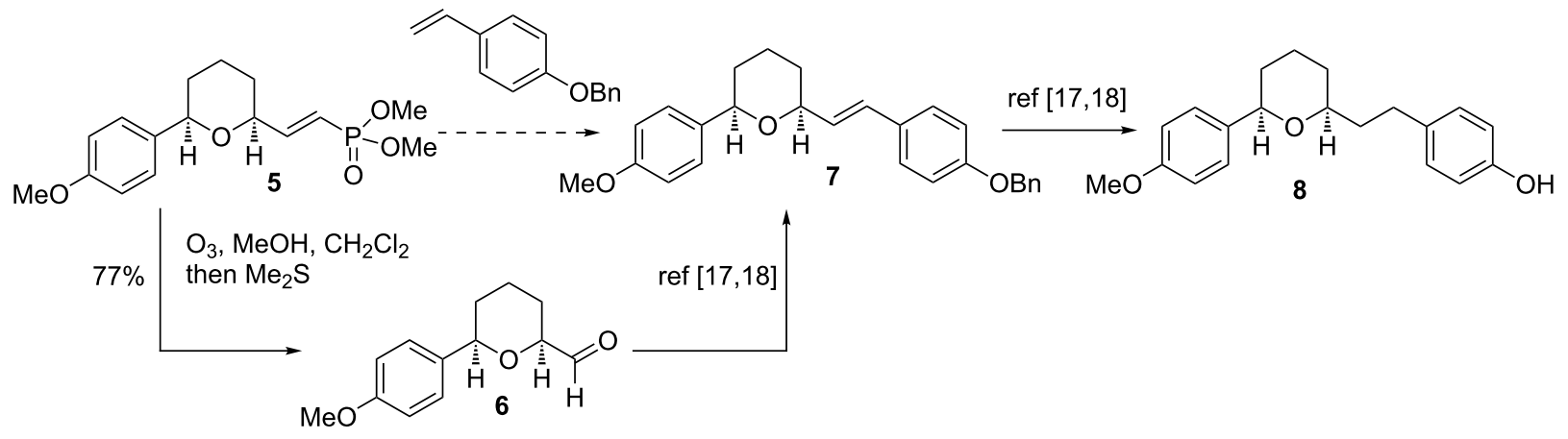


route to (-)-centrolobine (8). An alternative approach could involve an alkene cross metathesis reaction between the vinylphosphonate and a styrene (5 to 7 ).

Since substituted vinylphosphonates are reluctant to participate in cross metathesis reactions (Scheme 3), this approach to the synthesis of cetrolobine appeared to have little merit. However, Hoye et al. reported the concept of "relay ring closing metathesis (RRCM)", wherein typically unreactive $\alpha, \omega$-dienes bearing 1,1-disubstituted ethylene moieties 9 would react via the intermediacy of an additional terminal alkene $\mathbf{1 1}$ (Scheme 3) [19-21]. Similarly, Hansen and Lee employed an allyl ether to activate enynes toward cross metathesis [22]. Furthermore, there are several examples of vinylphosphonates participating in ring closing metathesis (RCM) reactions [23-25]. Therefore, given the propensity for vinylphosphonates to undergo RCM, it was proposed that an allyl phosphonate ester $\mathbf{1 4}$ would act as an initial site of metathesis, which would lead to a relay cross metathesis and thus render vinylphosphonates reactive.

\section{Results and Discussion}

A series of cross metathesis reactions were performed to establish the baseline reactivity of vinylphosphonates (Scheme 4). Not surprisingly, the terminal vinylphosphonate $\mathbf{1 5}$ underwent smooth cross metathesis with either 1-hexene or 1-heptene using our standard conditions ( $2 \%$ Grubbs II, $4 \% \mathrm{CuI} \mathrm{CH}_{2} \mathrm{Cl}_{2}$ reflux) $[2,26,27]$ to give the substituted vinylphosphonates $\mathbf{1 2 a}$ or $\mathbf{1 2 b}$ in good yield. In contrast, when vinylphosphonate $\mathbf{1 2 a}$ was subjected to a cross metathesis reaction with methyl acrylate, the cross metathesis product $\mathbf{1 6 a}$ was formed in low yield

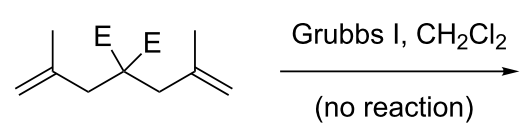

9, $\mathrm{E}=\mathrm{CO}_{2} \mathrm{Me}$<smiles>[R]C=CP(=O)(OC)OC</smiles>

12<smiles>CC1=C(C)CC(F)(F)C1</smiles>

10<smiles>C=CC(C)CC/C=C(\C)CC(F)(F)CC(=C)C</smiles>

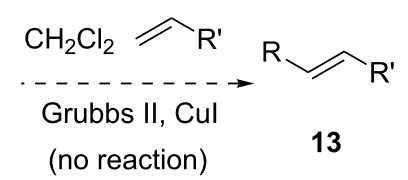

Scheme 3: Relay ring closing metathesis and relay cross metathesis.

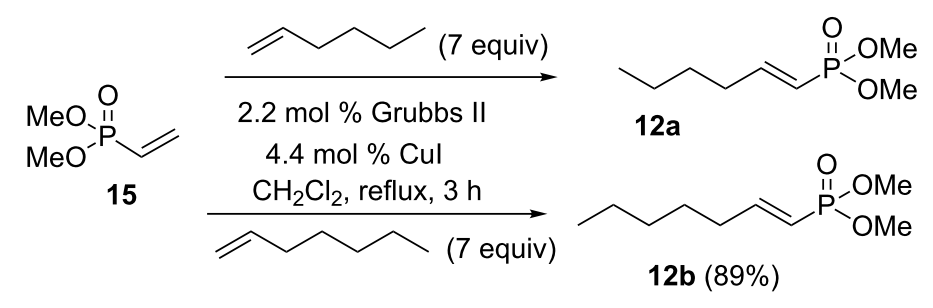

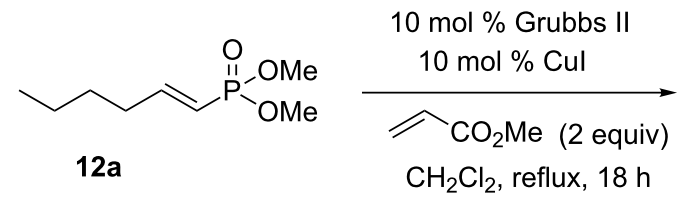<smiles>COc1ccc([C@H]2CCC[C@@H](/C=C/P(=O)(OC)OC)O2)cc1</smiles>

5<smiles>COP(=O)(/C=C/C1CCCO1)OC</smiles>

19
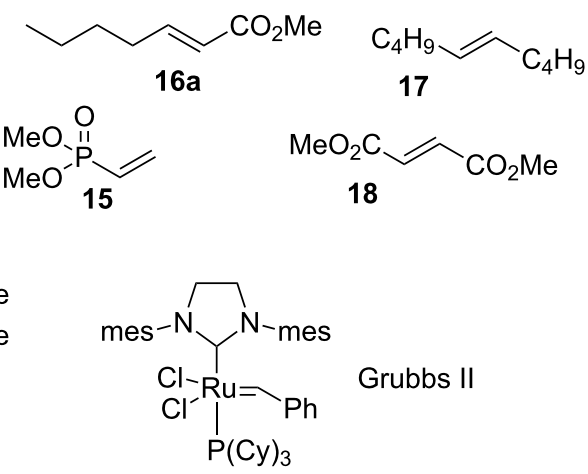
$(\sim 11 \%)$ as part of a complex mixture. More highly substituted vinylphosphonates (5 and 19) failed to react at all with methyl acrylate under similar conditions, even with higher catalyst loading and extended reaction times.

Initially, the synthesis of the allyl vinylphosphonate esters was achieved using a transesterification reaction catalysed by tetra $n$-butylammonium iodide (TBAI) (Scheme 5) [28]. A solution of the vinylphosphonate $\mathbf{1 2} \mathbf{b}, 1.1$ equivalents of allyl bromide and $5 \mathrm{~mol} \%$ TBAI in toluene was heated at reflux for 7 hours to give a $53 \%$ conversion to both the mono- and diallyl vinylphosphonates $\mathbf{1 4 a}$ and $\mathbf{1 4 b}$ in a 10:1 ratio. The overall conversion could be improved with excess allyl bromide, increasing the amount of TBAI and prolonged heating times, either at reflux or in a microwave reactor. The ratio of di- to mono-allyl phosphonate esters increases with the duration of reaction. A subsequent reaction of vinylphosphonate $\mathbf{1 2 b}$ employing 5 equivalents of allyl bromide, $5 \mathrm{~mol} \%$ TBAI and 18 hours at reflux resulted in $87 \%$ conversion with $1.2: 1$ ratio of mono- to diallyl ester (14a and 14b). The products were isolated by silica gel chromatography to give $31 \%$ yield of mono-allyl and $25 \%$ yield of diallyl phosphonate esters.

Similarly, THF-substituted vinylphosphonate 19 was treated with 5 equivalents of allyl bromide and $5 \mathrm{~mol} \%$ TBAI in refluxing toluene for 36 hours to give a $76 \%$ conversion with 1.8:1 ratio of mono- to diallylated vinyl phosphonates $\mathbf{2 0 a}$ and
$20 b$ (Scheme 5). The products were isolated by silica gel chromatography to give $46 \%$ yield of mono-allyl and $27 \%$ yield of diallyl phosphonate esters. Finally, THP-vinylphosphonate $\mathbf{5}$ was subjected to transesterification by reaction with $20 \mathrm{~mol} \%$ of TBAI and 5 equivalents of allyl bromide in toluene solution and heating in a microwave reactor for 5.5 hours. The reaction proceeded to $96 \%$ conversion and gave 1:1.8 ratio of mono- and diallyl vinylphosphonates $21 \mathbf{a}$ and $\mathbf{2 1 b}$. The products were isolated by silica gel chromatography to give $27 \%$ yield of the mono-allyl and $36 \%$ yield of the diallyl phosphonate esters.

With the mono- and diallyl vinylphosphonates in hand, the cross metathesis reactions with methyl acrylate (a type II olefin) were examined (Scheme 6). The mono-allyl vinylphosphonate 14a was treated with methyl acrylate, $10 \mathrm{~mol} \%$ Grubbs catalyst and $10 \mathrm{~mol} \% \mathrm{CuI}$ in refluxing $\mathrm{CH}_{2} \mathrm{Cl}_{2}$. The unsaturated ester 16b [29] was formed in 78\% yield (estimated from NMR). However, ester $\mathbf{1 6 b}$ is volatile and isolation by column chromatography resulted in some loss of material leading to an isolated yield of $45 \%$. In addition, the ${ }^{31} \mathrm{P}$ NMR spectrum of the crude reaction mixture indicated the formation of a new phosphoruscontaining product with a signal at $43 \mathrm{ppm}$, consistent with formation of the oxaphosphole 22 [25]. An impure sample of the oxaphosphole 22 was isolated by column chromatography, but it decomposed during attempts of further purification [23]. However, the ${ }^{31} \mathrm{P}$ NMR signal and the chemical shifts, multiplicities and coupling constants for the vinylic protons $[\mathrm{H} \alpha 7.16$<smiles>C=CCOP(=O)(/C=C/CCCCC)OCC=C</smiles>

$5 \%$ TBAI, 1.1 equiv allyl bromide reflux $7 \mathrm{~h}, 53 \%$ conversion, mono:di $=10: 1$ $10 \%$ TBAl, 5 equiv allyl bromide $\mu \mathrm{W}, 5.5 \mathrm{~h}, 62 \%$ conversion, mono: $\mathrm{di}=3: 1$ $10 \%$ TBAI, 5 equiv allyl bromide, $\mu \mathrm{W}, 5.5 \mathrm{~h}, 78 \%$ conversion, mono: $\mathrm{di}=1.8: 1$ $5 \%$ TBAI, 5 equiv allyl bromide reflux $18 \mathrm{~h}, 87 \%$ conversion, mono:di $=1.2: 1$ ( $31 \% \& 25 \%)$

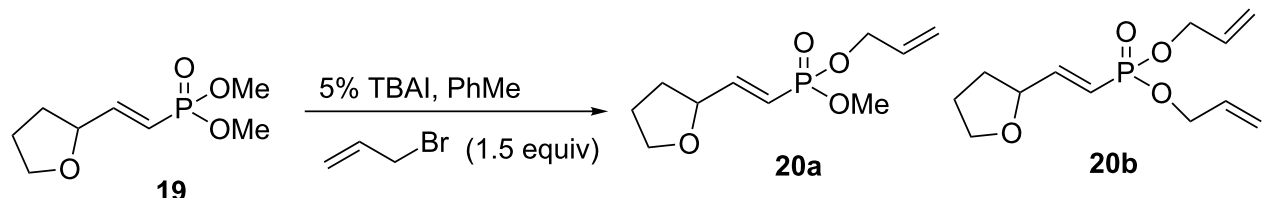
reflux $36 \mathrm{~h}, 76 \%$ conversion, mono:di $=1.8: 1(46 \% \& 27 \%)$<smiles>C=CCOP(=O)(/C=C/C1CCCC(c2ccc(OC)cc2)O1)OCC=C</smiles>

$\mu \mathrm{W}, 5.5 \mathrm{~h}, 96 \%$ conversion, mono:di $=1: 1.8(27 \% \& 36 \%)$ 


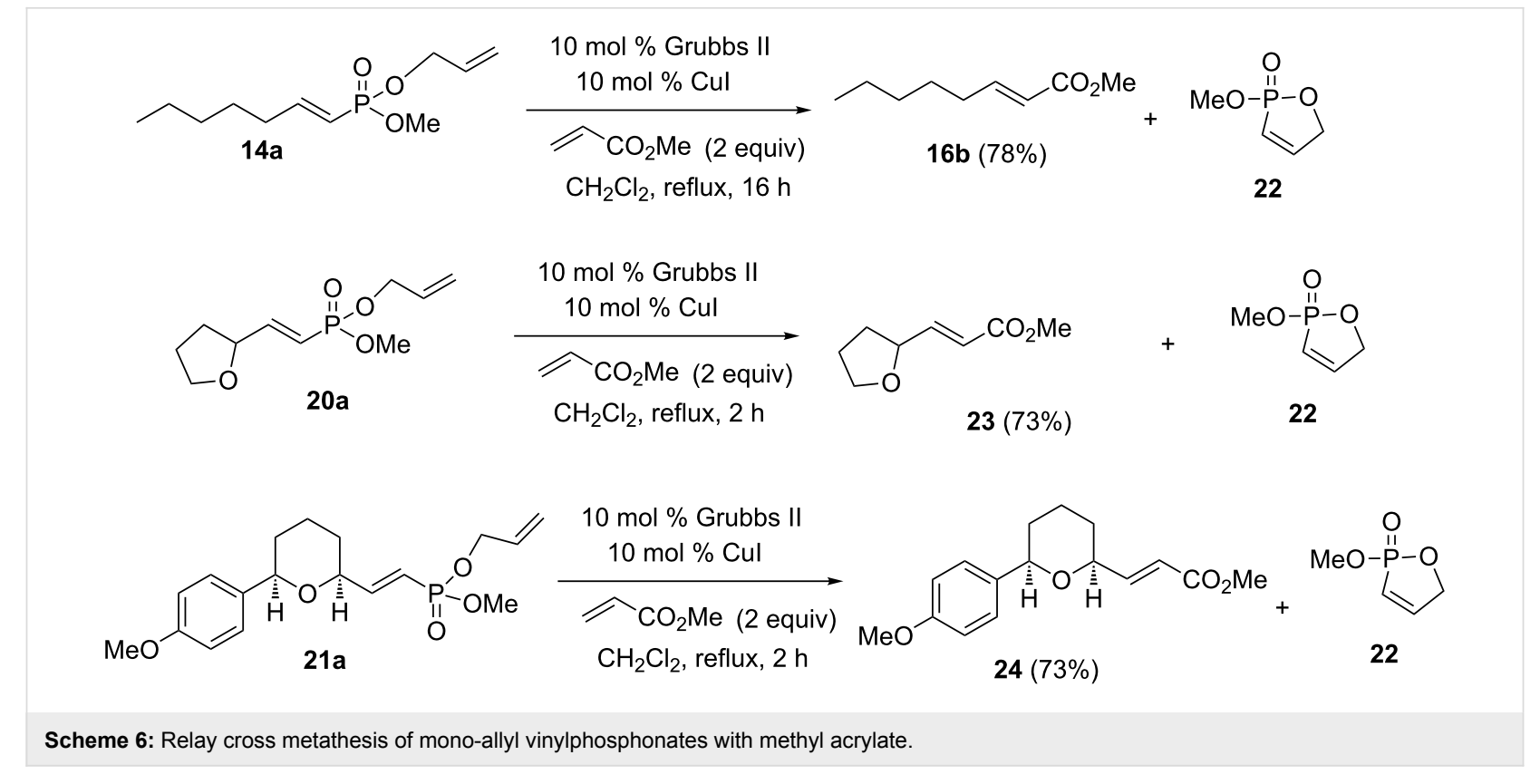

(ddt, $J_{\mathrm{HH}}=8.6, \sim 1 \mathrm{~Hz}, J_{\mathrm{Hp}}=46.9 \mathrm{~Hz}, 1 \mathrm{H}$ ) and $\mathrm{H} \beta, 6.2$ (ddt, $\left.J_{\mathrm{HH}}=8.6,2.3 \mathrm{~Hz}, J_{\mathrm{HP}}=33.9 \mathrm{~Hz}, 1 \mathrm{H}\right]$ in the ${ }^{1} \mathrm{H}$ NMR spectrum were very similar to those reported for similar structures [25] giving confidence in the structural assignment. The THFsubstituted allyl vinylphosphonate 20a and THP-substituted allyl vinylphosphonate 21a reacted under similar conditions to yield the unsaturated esters 23 [30] and 24, respectively.

The proposed synthesis of centrolobine (and analogs) (Scheme 2) required the cross metathesis reaction of the THPsubstituted allyl vinylphosphonate $\mathbf{2 1}$ a with substituted styrenes. $p$-Substituted styrenes are type I substrates and should readily engage in the metathesis reaction. Thus, reaction of the mono-allyl vinylphosphonate 21a with 5 equivalents of styrene using $10 \mathrm{~mol} \%$ Grubbs second generation catalyst and $10 \mathrm{~mol} \% \mathrm{CuI}$ in refluxing $\mathrm{CH}_{2} \mathrm{Cl}_{2}$ for two hours gave tetra- hydropyran $\mathbf{2 5}$ in $82 \%$ isolated yield (Scheme 7). Similarly, reaction of vinylphosphonate $\mathbf{2 1 a}$ with 4 -fluorostyrene and 4-benzyloxystyrene gave the tetrahydropyrans 26 and 7, respectively. Tetrahydropyran 7 is a known intermediate and can be converted to centrolobine by hydrogenation [17].

Surprisingly, the dimer 27 was isolated in small amounts ( $\sim 20 \%$ ) from the reaction of vinylphosphonate 21 a with styrenes. The dimeric product 27 was not observed during the cross metathesis of the vinylphosphonate 21a with methyl acrylate.

Diallyl vinylphosphonates (28) are reported to undergo ring closing metathesis to give either 7-membered (29) or 5-membered (30) phosphorus heterocycles (Scheme 8) [23,24]. The mode of cyclization depends upon the geometry and substi-

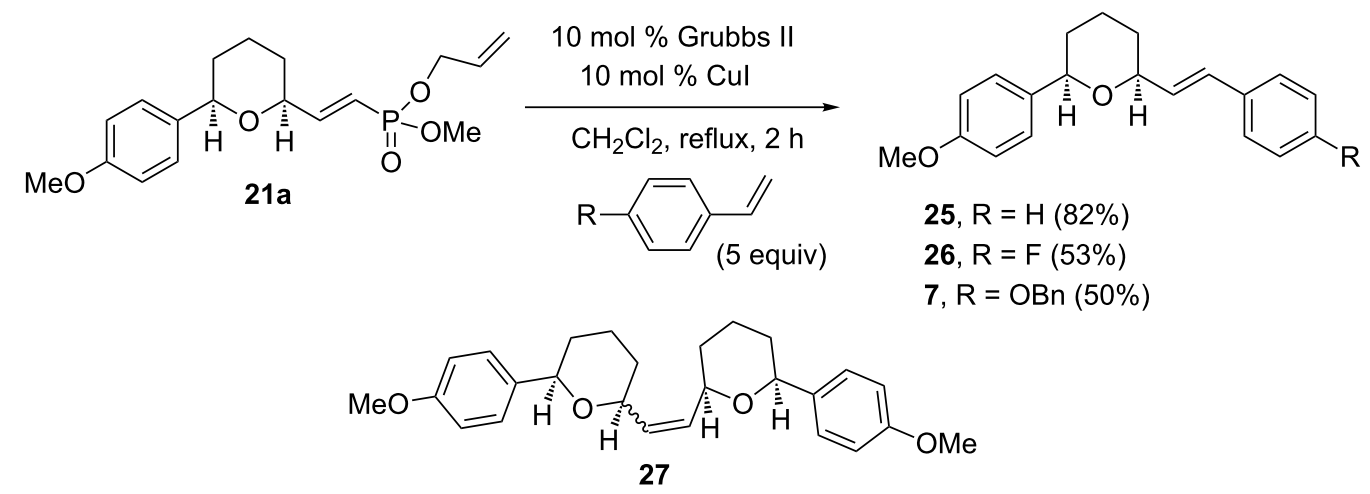




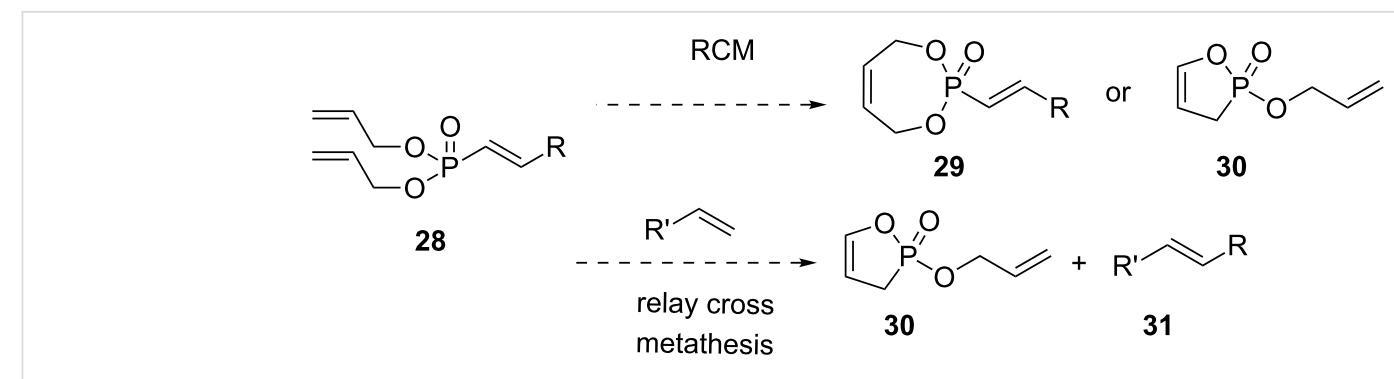

Scheme 8: Ring closing vs relay cross metathesis.

tution of the vinylphosphonate. It was proposed that $(E)$ diallyl vinylphosphonates would prefer to form the 5-membered ring oxaphosphole 30 and therefore, like the corresponding monoallyl phosphonates, should engage in relay cross metathesis reactions.

To test the hypothesis, the diallyl vinylphosphonate $\mathbf{1 4 b}$ was subjected to cross metathesis with methyl acrylate using standard conditions (Scheme 9). The corresponding cross metathesis product, unstaurated ester $\mathbf{1 6} \mathbf{b}$, was obtained with $45 \%$ conversion. Again, isolation resulted in some loss of product. ${ }^{31} \mathrm{P}$ NMR measurements also confirmed the formation of the 5-membered phosphate heterocycle 32. Similarly, diallyl phosphonate 21b was reacted with methyl acrylate to give the corresponding unsaturated ester $\mathbf{2 4}$ in good yield along with the phosphonate heterocycle 32. In general, reaction of either mono- allyl or diallyl vinylphosphonates with methyl acrylate proceeded with comparable yields.

The mono- and diallyl vinylphosphonates were first synthesized and then chromatographically separated before they were subjected to the cross metathesis reaction. In an ideal case, a single cross metathesis product would be formed from a crude mixture of mono-allyl and diallyl vinylphosphonates, avoiding the inefficiencies of chromatographic separation. A mixture of mono- and diallyl vinylphosphonates 14a and $14 \mathrm{~b}$ was subjected to cross metathesis reaction with methyl acrylate (Scheme 10). The reaction progress was monitored by<smiles>C=CCOP(=O)(/C=C/CCCCC)OCC=C</smiles><smiles>CCCCC/C=C/C(C)(C)C</smiles><smiles>C=CCOP(=O)(/C=C/C1CCC[C@H](c2ccc(OC)cc2)O1)OCC=C</smiles><smiles>COc1ccc([C@H]2CCC[C@@H](/C=C/C(C)=O)O2)cc1</smiles>

Scheme 9: Relay cross metathesis of diallyl vinylphosphonates with methyl acrylate.
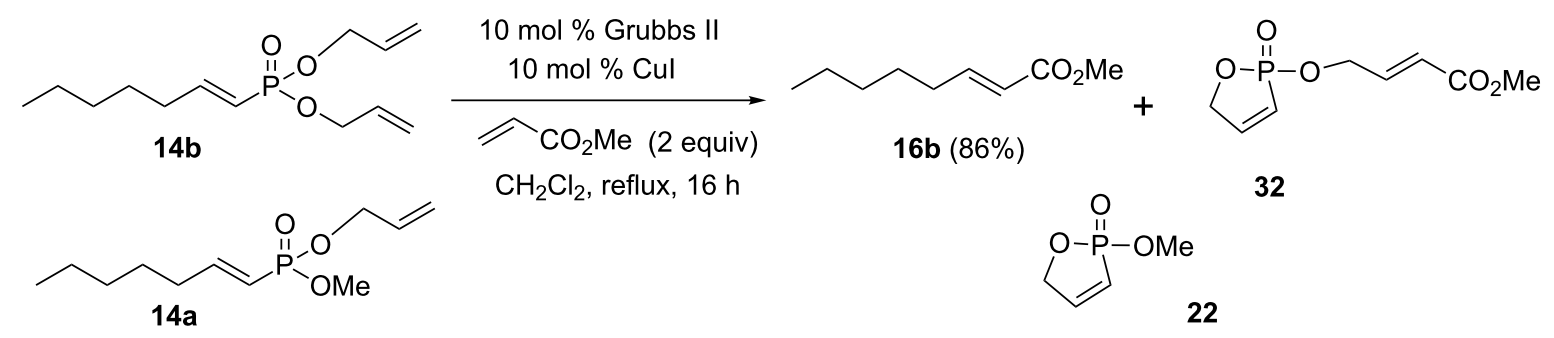

Scheme 10: A cross metathesis reaction of both mono- and diallyl vinylphosphonates with methyl acrylate. 
${ }^{31} \mathrm{P}$ NMR spectroscopy. After the reaction was complete, the ${ }^{31} \mathrm{P}$ NMR spectrum showed the formation of the two oxaphospholes 22 and $\mathbf{3 2}$ in a ratio corresponding to the amount of vinylphosphonates $\mathbf{1 4 a}$ and $\mathbf{1 4 b}$ in the starting material. Chromatographic separation of the crude product gave the unsaturated ester $\mathbf{1 6 b}$ in $86 \%$ isolated yield.

It is proposed that the Grubbs catalyst first reacts with the terminal alkene (Scheme 11) of the allyl phosphonate ester 21a to give the metal alkylidene 33. The metal alkylidene then reacts with the vinylphosphonate in a ring closing metathesis (RCM) to generate the oxaphosphole 22 and a new metal alkylidene 34. The sequence is completed by reaction of the metal alkylidene 34 with the metathesis partner (styrene) to give the tetrahydropyran $\mathbf{2 5}$. The formation of the dimeric product $\mathbf{2 7}$ is probably the result of a competitive cross metathesis reaction between the tetrahydropyran $\mathbf{2 5}$ and the metal alkylidene $\mathbf{3 4}$ [31].

Once the activation of vinylphosphonates toward cross metathesis was established, it became clear that the overall success of this method would depend on a selective, high yielding synthesis of mono-allyl phosphonates. The proposed mechanism of the TBAI catalyzed allylation (Scheme 12) involves cleavage of the $\mathrm{Me}-\mathrm{O}$ bond to form a phosphonate anion 35. The anion is re-alkylated with allyl bromide to produce the mono-allyl phosphonate $\mathbf{1 4 a}$. The major weakness of this approach is that the mono-allyl phosphonate can further react with iodide leading ultimately to the diallyl phosphonate 14b. Early in the reaction, the mono-allyl phosphonate is the dominant product. However, attempts to force the reaction with longer reaction times, increased TBAI, or increased ally bromide, leads to an increase in diallyl phosphonate $\mathbf{1 4 b}$.

Analysis of the TBAI allylation mechanism suggested that a good approach to mono-allyl phosphonate 14a would be a stoichiometric demethylation followed by a rapid allylation under ambient conditions. During the synthesis of phosphonate based ionic liquids, Sachnov et al. showed that ethylimidazole would reacted with dimethyl methylphosphonate to give ethylimidazolium methylphosphonate in quantitative yield [32]. We were pleased to observe $\left[{ }^{31} \mathrm{P} \mathrm{NMR}\right]$ that dimethyl vinylphosphonate 12b reacted with neat methylimidazole at $100{ }^{\circ} \mathrm{C}$ to give the imidazolium salt 37 (Scheme 13). Treatment of the salt with 5 equivalents of allyl bromide at room temperature for two days gave the mono-allyl phosphonate in $71 \%$ isolated yield (two steps). It is probable that this transesterification reaction can be further optimized to both increase yields and decrease the reaction time.

\section{Conclusion}

The experiments presented above have demonstrated that whereas the dimethyl esters of substituted vinylphosphonates are characterized as type IV substrates in alkene cross

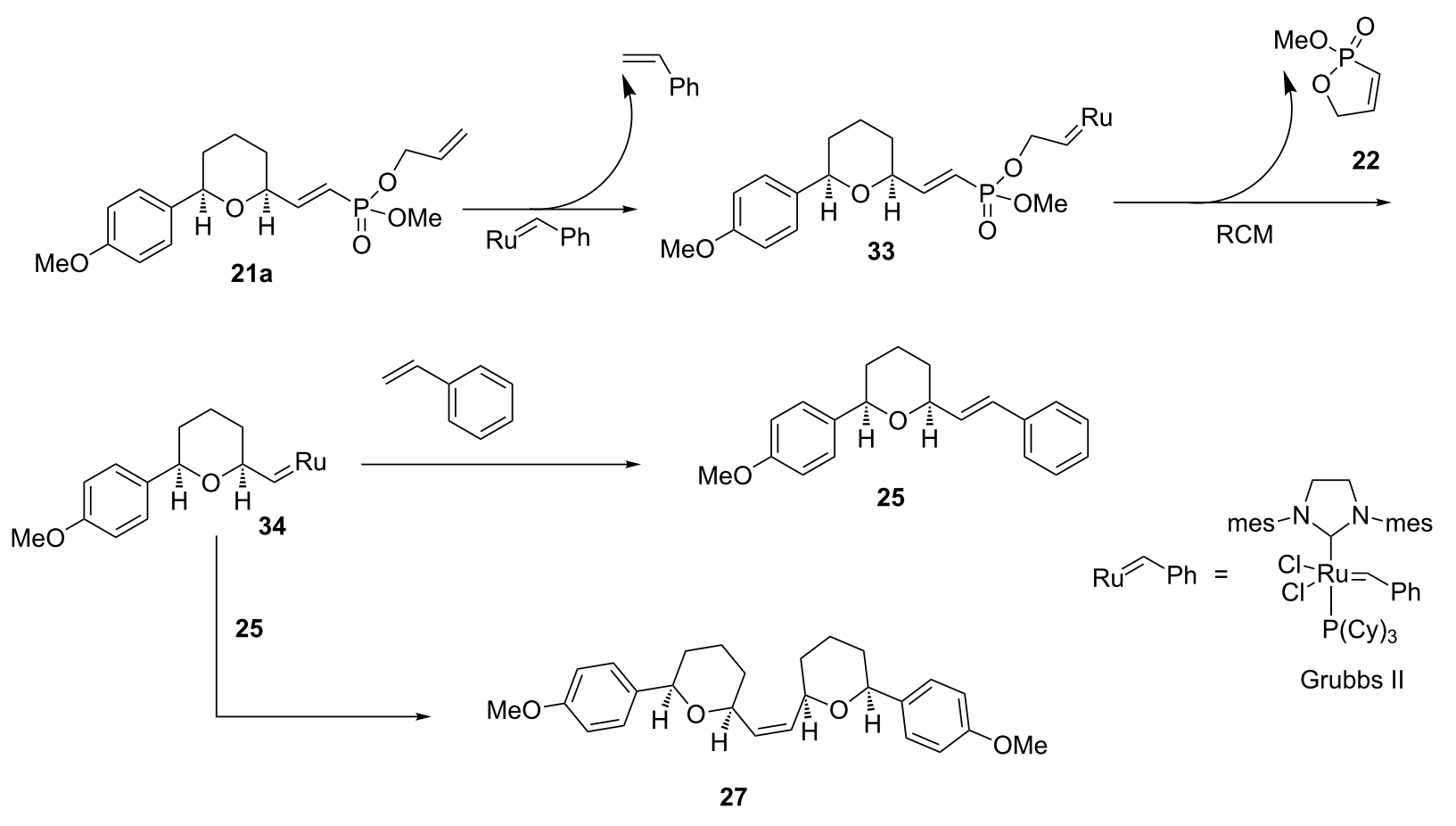




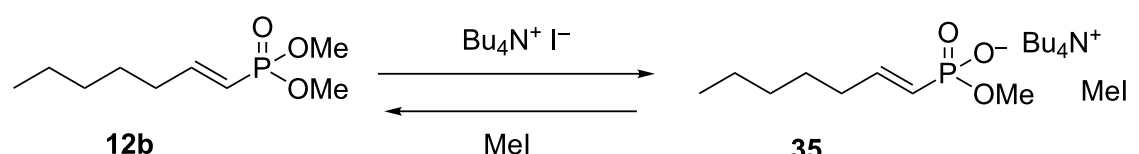

$12 b$

Mel

35

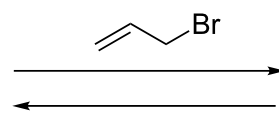

$\mathrm{Bu}_{4} \mathrm{~N}^{+} \mathrm{I}^{-}$<smiles>C=CCOP(=O)(/C=C/CCCCC)OC</smiles>

$14 a$

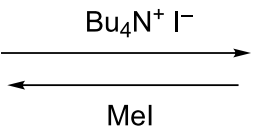

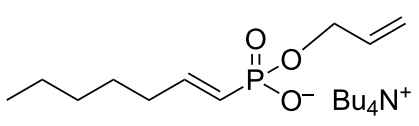

36

Mel

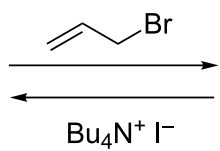

$\mathrm{Bu}_{4} \mathrm{~N}^{+}{ }^{-}$

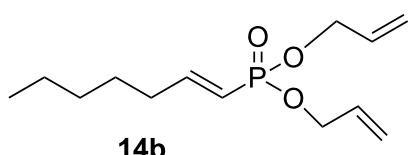

14b

Scheme 12: A proposed mechanism for the TBAl catalysed transesterification.<smiles>CCCCC/C=C/P(=O)(OC)OC</smiles><smiles>C=CCOP(=O)(/C=C/CCCCC)OC</smiles>

Scheme 13: A selective synthesis of mono-allyl phosphonates.

metathesis reactions and are unreactive, the corresponding allyl esters show significantly improved reactivity. The improved reactivity is attributed to relay step in the cross metathesis reaction mechanism.

\section{Supporting Information}

\section{Supporting Information File 1}

Experimental procedures, characterization data, ${ }^{1} \mathrm{H}$ and ${ }^{13} \mathrm{C}$ spectra for all new compounds.

[http://www.beilstein-journals.org/bjoc/content/ supplementary/1860-5397-10-201-S1.pdf]

\section{References}

1. Shabany, H.; Spilling, C. D. Tetrahedron Lett. 1998, 39, 1465-1468. doi:10.1016/S0040-4039(97)10837-1

2. De la Cruz, A.; He, A.; Thanavaro, A.; Yan, B.; Spilling, C. D.; Rath, N. P. J. Organomet. Chem. 2005, 690, 2577-2592. doi:10.1016/j.jorganchem.2004.11.019
3. Yan, B.; Spilling, C. D. J. Org. Chem. 2008, 73, 5385-5396. doi:10.1021/j08004028

4. Rowe, B. J.; Spilling, C. D. J. Org. Chem. 2003, 68, 9502-9505. doi:10.1021/jo0351318

5. Yan, B.; Spilling, C. D. J. Org. Chem. 2004, 69, 2859-2862. doi:10.1021/jo035795h

6. Bandyopadhyay, S.; Dutta, S.; Spilling, C. D.; Dupureur, C. M.; Rath, N. P. J. Org. Chem. 2008, 73, 8386-8391. doi:10.1021/jo801453v

7. Roy, S.; Spilling, C. D. Org. Lett. 2010, 12, 5326-5329. doi:10.1021/ol102345v

8. Roy, S.; Spilling, C. D. Org. Lett. 2012, 14, 2230-2233. doi:10.1021/ol300597u

9. He, A.; Sutivisedsak, N.; Spilling, C. D. Org. Lett. 2009, 11, 3124-3127. doi:10.1021/ol900980s

10. Chatterjee, A. K.; Choi, T.-L.; Grubbs, R. H. Synlett 2001, 1034-1037. doi:10.1055/s-2001-14654

11. Chatterjee, A. K.; Choi, T.-L.; Sanders, D. P.; Grubbs, R. H. J. Am. Chem. Soc. 2003, 125, 11360-11370. doi:10.1021/ja0214882

12. De Albuquerque, I. L.; Galeffi, C.; Casinovi, C. G.; Marini-Bettolo, G. B. Gazz. Chim. Ital. 1964, 94, 287.

13. Galeffi, C.; Casinovi, C. G.; Marini-Bettolo, G. B. Gazz. Chim. Ital. 1965, 95, 95. 
14. Craveiro, A. A.; da Costa Prado, A.; Gottlieb, O. R.; Welerson de Albuquerque, P. C. Phytochemistry 1970, 9, 1869-1875. doi:10.1016/S0031-9422(00)85606-X

15. Jurd, L.; Wong, R. Y. Aust. J. Chem. 1984, 37, 1127-1133. doi: $10.1071 / \mathrm{CH} 9841127$

16. Sudarshan, K.; Aidhen, I. S. Eur. J. Org. Chem. 2013, 2298-2302. doi:10.1002/ejoc.201300097

And references cited therein. See for the syntheses of $(+)$ and (-)-centrolobine.

17. Colobert, F.; Des Mazery, R.; Solladié, G.; Carreño, M. C. Org. Lett. 2002, 4, 1723-1725. doi:10.1021/ol025778z

18. Prasad, K. R.; Anbarasan, P. Tetrahedron 2007, 63, 1089-1092. doi:10.1016/j.tet.2006.11.062

19. Hoye, T. R.; Jeffrey, C. S.; Tennakoon, M. A.; Wang, J.; Zhao, H. J. Am. Chem. Soc. 2004, 126, 10210-10211. doi:10.1021/ja046385t

20. Hoye, T. R.; Zhao, H. Org. Lett. 1999, 1, 1123-1125. doi:10.1021/ol990947+

21. Hoye, T. R.; Jeon, J. Metathesis Involving a Relay and Applications in Natural Product Synthesis. In Metathesis in Natural Product Synthesis: Strategies, Substrates and Catalysts; Cossy, J.; Arseniyadis, S.;

Meyer, C., Eds.; Wiley VCH: Weinheim, Germany, 2010; pp 261-285.

22. Hansen, E. C.; Lee, D. Org. Lett. 2004, 6, 2035-2038. doi:10.1021/ol049378i

23. Hanson, P. R.; Stoianova, D. S. Tetrahedron Lett. 1998, 39, 3939-3942. doi:10.1016/S0040-4039(98)00728-X

24. Hanson, P. R.; Stoianova, D. R. Tetrahedron Lett. 1999, 40, 3297-3300. doi:10.1016/S0040-4039(99)00479-7

25. Timmer, M. S. M.; Ovaa, H.; Filippov, D. V.; van der Marel, G. A.; van Boom, J. H. Tetrahedron Lett. 2000, 41, 8635-8638. doi:10.1016/S0040-4039(00)01511-2

26. Rivard, M.; Blechert, S. Eur. J. Org. Chem. 2003, 2225-2228. doi:10.1002/ejoc.200300215

27. He, A.; Yan, B.; Thanavaro, A.; Spilling, C. D.; Rath, N. P. J. Org. Chem. 2004, 69, 8643-8651. doi:10.1021/jo0490090

28. Malla, R. K.; Bandyopadhyay, S.; Spilling, C. D.; Dutta, S.; Dupureur, C. M. Org. Lett. 2011, 13, 3094-3097. doi:10.1021/ol200991x

29. Trost, B. M.; Ball, Z. T.; Jöge, T. J. Am. Chem. Soc. 2002, 124, 7922-7923. doi:10.1021/ja026457।

30. Trost, B. M.; Li, C.-J. J. Am. Chem. Soc. 1994, 116, 10819-10820. doi:10.1021/ja00102a071

31. A reviewer suggested that perhaps dimer 27 is more efficiently formed from a sequence of unproductive cross metathesis (i.e., metal exchange) of ruthenium alkylidene $\mathbf{3 4}$ with either ethylene or allyl phosphonate $\mathbf{2 1 a}$, followed by homodimerization of the resulting vinyltetrahydropyran.

32. Sachnov, S. J.; Schulz, P. S.; Wasserscheid, P. Chem. Commun. 2011, 47, 11234-11236. doi:10.1039/c1cc14490a

\section{License and Terms}

This is an Open Access article under the terms of the Creative Commons Attribution License

(http://creativecommons.org/licenses/by/2.0), which permits unrestricted use, distribution, and reproduction in any medium, provided the original work is properly cited.

The license is subject to the Beilstein Journal of Organic Chemistry terms and conditions:

(http://www.beilstein-journals.org/bjoc)

The definitive version of this article is the electronic one which can be found at:

doi:10.3762/bjoc. 10.201 